Article

\title{
Willingness to Pay for Improved Household Solid Waste Collection in Blantyre, Malawi
}

\author{
Hanke Ndau ${ }^{1}$ and Elizabeth Tilley ${ }^{1,2, * \mathbb{B}}$ \\ 1 University of Malawi, The Polytechnic, Chichiri 3, Blantyre, Malawi; ndauhanke@gmail.com \\ 2 Eawag: Swiss Federal Institute of Aquatic Science and Technology, CH-8600 Dübendorf, Switzerland \\ * Correspondence: elizabeth.tilley@eawag.ch
}

Received: 27 April 2018; Accepted: 20 September 2018; Published: 9 October 2018

check for updates

\begin{abstract}
Insufficient staff, inappropriate collection vehicles, limited operating budgets and growing, hard to reach populations mean that solid waste management remains limited in most developing countries; Malawi is no exception. We estimated the willingness to pay (WTP) for two hypothetical solid waste collection services. Additionally, we tested the impact of the WTP question positioning relative to environmental perceptions on respondents' WTP. The first scenario involved a five minute walk to a disposal facility; the second scenario involved a $30 \mathrm{~min}$ walk. Additionally, the order of the question was randomized within the questionnaire. A WTP value of K1780 was found for the five minute walk scenario when the question was placed first, and K2138 when placed after revealing the respondent's perceptions on the environment. In the 30 min walk scenario, WTP was K945 when placed first and K1139 when placed after revealing the respondent's perceptions on the environment. The estimated values indicate that there is both a willingness to pay for solid waste services and that there are at least two options that would be acceptable to the community; a pilot scale implementation would be required to validate the hypothetical values, especially given the dependency on problem framing. Community financing should be considered as a sustainable approach to solid waste management in underserved areas.
\end{abstract}

Keywords: solid waste; Malawi; WTP; dichotomous choice; Africa; service delivery

JEL Classification: D120; D640; I100; I150; Q200

\section{Introduction}

Adequate management of solid waste should promote minimum waste generation, and include regular collection, voluntary separation, safe and adequate storage, effective treatment and safe disposal (UN-Habitat 2012). Poor waste management reduces the quality of life by providing food and breeding conditions for vermin and disease vectors, producing odor, diminishing aesthetics and contaminating surface and ground water (Hoornweg and Bhada-Tata 2012).

Financing for the transport, human resources, and facilities that are required is usually supplied via some sort of tax base, but in resource-poor environments, solid waste management (SWM) is usually under-funded and as a result, poorly managed.

Located in the southern region of Malawi, Blantyre is a commercial city as well as the second largest city in the country. The population of Blantyre was 661,256 in 2008 (National Statistical Office 2008). Over $70 \%$ of the population lives in unplanned areas, which occupies $23 \%$ of the land area in Blantyre (UN-Habitat 2012). Although there is collection (and semi-controlled dumping) of waste in formal areas, informal areas are left unserved (Palamuleni 2002; Government of Malawi 2010; Maoulidi 2012; Maganga 2013; Barre 2014). Poor solid waste management is common in Malawi (indeed in most 
developing countries), and is partly a result of inadequate financing, institutional will and capacity (Maganga 2013; Barre 2014).

Where waste is not collected by the city, it is left on road sides and river banks, which has resulted in surface and ground water contamination (Palamuleni 2002). Given the lack of institutional support, some cities have adopted independent or community-led solutions. The challenge however remains knowing how much, if anything, residents would pay to an independent contractor to fill the role that is left empty by the authorities (i.e., regular collection, transport and disposal).

The value of a good or service can be solicited through the good or service's revealed preference or stated preference. A revealed preference is estimated by how much is actually paid or spent on a good or service, i.e., the worth is revealed by present actions. A stated preference, on the other hand, is theoretical and though realistic in the respondent's mind, may not be true once tested, or revealed.

Stated preference methods are often used to compare the costs and benefits of policy changes before they actually happen (DEFRA 2007). The ultimate goal is to estimate the total economic value of a good or service which does not have a pre-determined market price, such as solid waste collection, though it has not been used extensively for this specific purpose (Breffle et al. 1998). A variety of methods exist, but the double-bound dichotomous choice method is relatively quick and simple for the respondent (compared to a choice experiment) and generates a more precise range for willingness to pay (WTP) (DEFRA 2007; Cameron and Quiggin 1994; Lopez-Feldman 2012). By using the dichotomous choice format, accuracy is increased as more data points are fitted to the function for willingness to pay. Clear boundaries are yielded from the sequential bid offers (Cameron and Quiggin 1994).

In Malaysia, contingent valuation was used to estimate the benefits of improved solid waste management in Kuala Lumpur: households were willing to pay slightly more for the system involving voluntary source separation than for the system where it was mandatory, though the difference was insignificant (Afroz and Masud 2011). In Malawi, dichotomous contingent valuation was used to determine the willingness to pay for solid waste collection in Lilongwe, and was found to be K92 per household per month (Maganga 2013).

Although stated preference methods can provide results that are exaggerated up or down (Bateman et al. 2001; Hensher 2010), there is limited, but growing evidence to show that preferences obtained through valuation are useful in revealing an individual's perceptions towards policies that have not yet been implemented (Tilley and Günther 2016). In the environmental sanitation sector, some work has used stated preference methods for solid waste (Czajkowski et al. 2014) however, across all disciplines there are few examples of stated preferences being validated against revealed preferences, partly because few of the tested scenarios are implemented, or because they are too abstract to do so.

South Lunzu is a large, fast growing area within the boundaries of Blantyre and without waste collection services. It does, however, have roads and limited coverage of water and electricity, which indicate growing wealth and a population that could consider paying for solid waste collection. Therefore, in order to determine the willingness to pay for this service, we used a double bounded dichotomous choice contingent valuation. Furthermore, we compared the willingness to pay for a self-collection service with that of a kerbside (roadside) collection service and tested the impact of environmental framing with regard to the stated WTP value.

Findings from this research can be used to identify opportunities for recycling, improve environmental conditions, create business opportunities in waste management, create employment, and further increase investments in the solid waste value chain.

\section{Methodology}

A dichotomous choice questionnaire was used to solicit WTP estimates; socioeconomic characteristics, household practices and opinions about SWM, as well as questions related to concern for the environment were also collected (Afroz and Masud 2011; Maganga 2013). The detailed questionnaire is in Appendix A. 


\subsection{Starting Bids}

In order to solicit the WTP for solid waste management, a dichotomous choice contingent valuation method was used. First, the respondent was presented with a scenario for solid waste collection and a fee that would be paid for the service. If the response was yes to this question, a second question followed, and this offer was double the amount of money presented in the first question. If the respondent refused to pay the amount presented in the first question, then the second question contained half of the initial amount presented (Bateman et al. 2001; Cameron and Quiggin 1994).

The questionnaire was pre-tested on a similar sample prior to the final data collection. The sample population for the pre-test was randomly selected from the same area of interest. The pre-test results were used to refine the contingent valuation questions as well as derive parameters that were used to calculate the actual sample size. The pre-test was also used to train enumerators. Respondents were asked to comment on the clarity as well as the difficulty of the questions at the end of each interview session during the pilot study. The questionnaires in both the pre-test and the final data collection were administered in person by trained enumerators.

Uncertain respondents have a tendency to focus their response near to the suggested amount in single bounded dichotomous choice questions. If poorly planned, double bounded dichotomous choice valuation may result in WTP values centered around the suggested amounts. This kind of respondent bias is known as anchoring. The kind of question design that halves or doubles the suggested amount in the initial question reduces the impact of starting point bias which is caused by uncertain respondents that anchor their willingness to pay on the bid amount presented in the first question (Carmona-Torres and Calatrava-Requena 2006). Doubling the amount presented in the initial bid ensures that the follow up bid crossed the respondent's anchoring threshold, as such, the bids represent both extremes of WTP.

In both the pre-test questionnaire and the final questionnaire, there were five starting bids (Carmona-Torres and Calatrava-Requena 2006; Honu 2007). During the pre-test, the initial bids were K1000, K3000, K5000, K7000 and K9000. The follow up bids covered values from K500 to K18,000 (at the time of writing the exchange rate was approximately K750/\$USD and GDP was 1169 (current international \$, 2016) (World Bank. 2018). The bid amounts in the pre-test questionnaire were spread widely so as to include as many WTP values as possible. The distribution of "yes" responses from the pre-test was measured as the probability of an individual agreeing to participate at that fee. The pilot results showed that most respondents were willing to participate when the amounts offered were between $\mathrm{K} 500$ and K10,000. In the final questionnaire the initial bid amounts used were K1000, K2000, $\mathrm{K} 3000$, K4000 and K5000, and thus the follow up bids had a maximum amount of K10,000 as shown in Table 1.

Table 1. Bid amounts.

\begin{tabular}{|c|c|c|}
\hline \multirow[t]{2}{*}{ Initial Bid } & \multicolumn{2}{|c|}{ Follow up Bids } \\
\hline & If Answer to Initial Is "Yes" & If Answer to Initial Is "No" \\
\hline \multicolumn{3}{|c|}{ Pilot Study } \\
\hline 1000 & 2000 & 500 \\
\hline 3000 & 6000 & 1500 \\
\hline 5000 & 10,000 & 2500 \\
\hline 9000 & 18,000 & 3500 \\
\hline \multicolumn{3}{|c|}{ Final Study } \\
\hline 1000 & 2000 & 500 \\
\hline 2000 & 4000 & 2000 \\
\hline 3000 & 6000 & 1500 \\
\hline 4000 & 8000 & 2000 \\
\hline 5000 & 10,000 & 2500 \\
\hline
\end{tabular}




\subsection{Hypothetical Solid Waste Management System}

In one set of the questionnaires, the hypothetical scenario and willingness to pay questions were presented before any other questions (e.g., demographic) and in the other set, the hypothetical scenario and WTP questions were presented after the section on opinions towards present solid waste management practice. One of the hypothetical waste collection systems was a kerbside (roadside) collection system whereby the household would be required to place waste containers on the road side near the house for collection on a specific day of the week. The waste would then be transported to a transfer station or disposal site by bicycle carts and small trucks. Payment would be on monthly basis to a community-managed fund that would cover the cost of operations.

The second system would require household members to carry the waste to a transfer station. An appointed entity would then transport the waste out of the area. The payment and management method would remain the same in both scenarios. Additionally, the WTP questions were randomized, so that they were placed either before or after some questions about the respondents' views on the environment. For example, we asked: "Among the following environmental issues, which of these deserves the most attention: water pollution, air pollution, deforestation, solid waste management, etc." which primed the respondent for thinking about the environment and their priorities. Altering the placement of the question allowed us to test the impact of framing, i.e., preparing the respondents' mind to more fully consider the implications of their choice.

A summary of the scenarios is presented in Table 2.

Table 2. Description of hypothetical scenarios.

\begin{tabular}{ccc}
\hline System Attribute & Scenario 1: & Scenario 2: \\
\hline Collection frequency & Once a week & Whenever storage container is full \\
\hline Distance to collection point & Road nearest to respondent's house & $\begin{array}{c}\text { Commal space e.g., market nearest to } \\
\text { respondent's house }\end{array}$ \\
\hline Travel time required & 5 min to disposal & 30 min to disposal \\
\hline Travel frequency to collection point & Once a week on the collection day & Whenever suitable for household members \\
\hline Other requirements for participation & $\begin{array}{c}\text { Plastics, food waste, glass, metals and } \\
\text { yard waste in separate plastic bags }\end{array}$ & $\begin{array}{c}\text { Plastics, food waste, glass, metals and yard } \\
\text { waste in separate plastic bags }\end{array}$ \\
\hline Payment form & $\begin{array}{c}\text { Household pays a monthly fee to a } \\
\text { community managed account }\end{array}$ & $\begin{array}{c}\text { Household pays a monthly fee to a } \\
\text { community managed account }\end{array}$ \\
\hline
\end{tabular}

\subsection{Sample Design}

Ten households were selected from each of the five internal subdivisions in South Lunzu for a sample of 50 households for the pilot study. The tenth household from a chosen junction in a street was selected as the first household in the sample. Subsequent households along the street were selected using the same interval of ten, whilst alternating sides of the street, until the tenth household in the area was selected.

The final sample size was calculated using the standard deviation ( $\sigma \mathrm{p})$ and the standard error (E) of the WTP from the pilot (Triola 2001).

From the pilot study, mean WTP for scenario one was K3315 with a standard deviation of K4491 and a standard error of K717. As a result, the target minimum sample size for the final study was calculated to be 841 households. In scenario two, the pilot study resulted in a mean WTP of K3493 with a standard deviation of K3459 and a standard error of K567, giving a minimum sample size of 1412 households. Due to time and resource limitations 1250 households were included in the final study. Like in the pilot survey, the 10th household on a street was also selected from each sub-division. Using the interval of 10 , a total of 250 households were sampled from each of the five selected sub-divisions. 


\subsection{Analysis}

The Dichotomous Choice Contingent Valuation model was proposed by Hanemann et al. (1991) and further developed by Cameron and Quiggin (1994). The "doubleb" command developed by Lopez-Feldman (2012) in STATA version 12 was used to estimate the WTP and the impact of other variables on WTP. The "doubleb" command estimates maximum likelihood under the assumption of normality.

The Dichotomous Choice Contingent Valuation model as developed by Cameron and Quiggin (1994) assumes normal distribution of WTP and that the WTP of individual $i$ can be modelled as the following linear function:

$$
\operatorname{WTP}_{i}\left(z_{i}, u_{i}\right)=z_{i} \beta+u_{i}
$$

where $z_{i}$ is a vector of explanatory variables, $\beta$ is a vector of their corresponding coefficients and $u_{i}$ is random error term. It is expected that the individual (i) will answer "yes" when $W T P_{i}$ is greater than or equal to the suggested amount $\left(t_{i}\right)$, (i.e., when $W T P_{i} \geq t_{i}$ ) and will answer "no" when $W T P_{i}$ is less than the suggested amount $\left(t_{i}\right)$, (i.e., when $\left.W T P_{i}<t_{i}\right)$.

To find $\beta$, the following maximum likelihood function was used

$$
\begin{aligned}
\log L=\sum_{i=1}^{N}\left[d_{i}^{s n}\right. & \ln \left(\Phi\left(z_{i}^{\prime} \frac{\beta}{\sigma}-\frac{t_{1}}{\sigma}\right)-\Phi\left(z_{i}^{\prime} \frac{\beta}{\sigma}-\frac{t_{2}}{\sigma}\right)\right)+d_{i}^{s s} \ln \left(\Phi\left(z_{i}^{\prime} \frac{\beta}{\sigma}-\frac{t_{2}}{\sigma}\right)\right) \\
& +d_{i}^{n s} \ln \left(\Phi\left(z_{i}^{\prime} \frac{\beta}{\sigma}-\frac{t_{2}}{\sigma}\right)-\Phi\left(z_{i}^{\prime} \frac{\beta}{\sigma}-\frac{t_{1}}{\sigma}\right)\right) \\
& \left.+d_{i}^{n n} \ln \left(1-\Phi\left(z_{i}^{\prime} \frac{\beta}{\sigma}-\frac{t_{2}}{\sigma}\right)\right)\right]
\end{aligned}
$$

where $d_{i}^{s n}, d_{i}^{s s}, d_{i}{ }^{n s}, d_{i}{ }^{n n}$ are indicator variables that take the value of one or zero depending on the response from each individual. $d_{i}^{s n}$ takes the value " 1 " if the respondent says "yes" to the first question and "no" to the second question. $d_{i}^{\text {ss }}$ takes the value of " 1 " when the respondent answers "yes" to both questions. $d_{i}{ }^{n s}$ takes the value " 1 " when the respondent answers "no" to the first question and "yes" to the second question. $d_{i}{ }^{n n}$ takes the value " 1 " when the respondent answers "no" to both questions. From the setup of the questions, the responses will generate a value of 1 in only one part of Equation (2), and the rest will take the value of 0 . The respondent will thus contribute to the logarithmic function in only one of its parts as all the other parts will be equal to 0 . After finding $\beta$ and $\sigma$, the WTP for each individual was estimated using Equation (3):

$$
\operatorname{WTP}_{i}\left(z_{i}, \beta\right)=\sum z_{i} \beta
$$

\subsection{Ethical Considerations}

All respondents gave verbal consent to participate in the study. Due to low levels of literacy in the area, the questions were read out to the respondents in the language they were more comfortable with (English or the local language, Chichewa). Permission to conduct the study was granted from local leaders (chiefs). A local representative was appointed to accompany the enumerators wherever it was deemed necessary by the local leadership.

There were several cases where household members requested consultation from the local leaders or head of households before participating. These households were revisited later on an agreed day. The respondents' names were not recorded, and a unique ID number identified households.

\section{Results}

We obtained 1256 valid responses. A breakdown of the household characteristics is presented in Table 3. In order to determine the quantity of waste generated, respondents were shown a two liter 
basin and asked how many basins of that size they would fill up each day. They were also asked to estimate how long it took them to travel to their current waste disposal site.

Table 3. Sample characteristics.

\begin{tabular}{cccccc}
\hline & & \multicolumn{2}{c}{ Pilot Study } & \multicolumn{2}{c}{ Final Study } \\
\hline Variable & Units & $\boldsymbol{n}$ & Mean & $\boldsymbol{n}$ & Mean \\
\hline Age & Years & 47 & 40.45 & 1196 & 29.93 \\
Household size & Pop/HH & 50 & 5.1 & 1221 & 5 \\
Years in South Lunzu & Years & 47 & 8 & 1228 & 4.94 \\
Years in present house & Years & - & - & 1223 & 3.90 \\
Household income & K/month & 47 & 90,266 & 1200 & 111,512 \\
Daily solid waste quantity & L/day & 50 & 1.40 & 1234 & 1.49 \\
Time taken to travel to disposal site & Minutes & 47 & 6.70 & 1233 & 6.66 \\
\hline
\end{tabular}

\section{Willingness to Pay}

In both scenarios, the number of yes responses decreased as the initial bid amount was increased. The highest number of yes responses was made to the lowest initial bid. The five minute walk scenario had more yes responses to the initial bid compared to the 30 min walk scenario. Figure 1 presents a summary of the trend in responses.

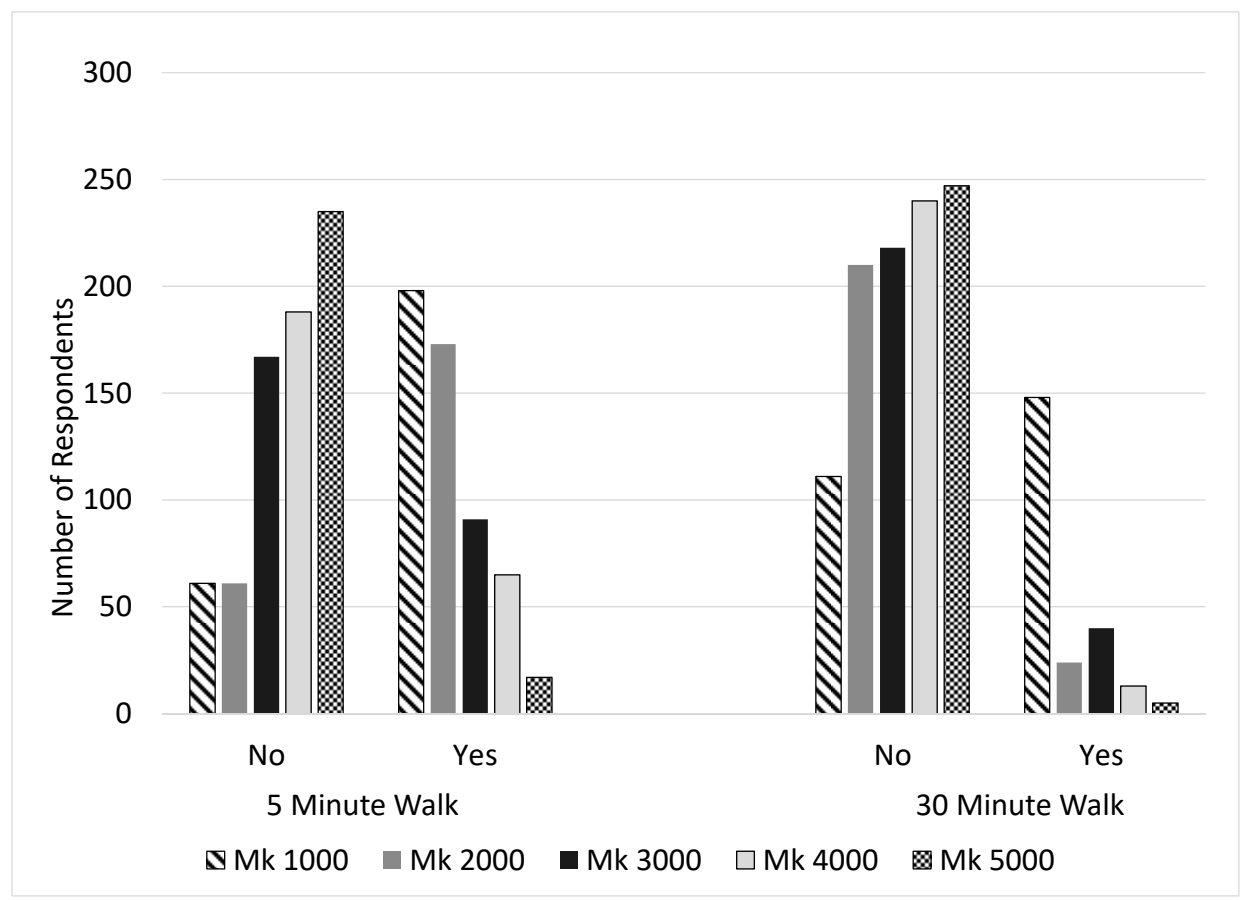

Figure 1. Response trends as bid amounts were increased.

WTP was estimated to be K716 when the walking time to the disposal site was 30 min (scenario two). When the walking time to the disposal site was reduced to five minutes (scenario one), the average WTP increased to K1980. These were the averages calculated while all other variables were held constant.

Table 4 shows the impact of the covariates on WTP estimations: Position of valuation question (first in questionnaire $=0$ ), age (years), gender (male $=1$ ), education (some formal education $=1$ ), house owners (owners $=1$ ), years in present house (years), years in South Lunzu (years), employment status (employed $=1$ ), household income (K per month), walking with bag of waste (walk = 1, onsite = 0 ), satisfaction for SWM (satisfied =1), ranking for SWM compared to other priorities (SWM highest ranked $=1$, other position $=0$ ). 
Table 4. Willingness to pay models.

\begin{tabular}{|c|c|c|c|c|c|c|c|c|}
\hline & 1 & 2 & 3 & 4 & 5 & 6 & 7 & 8 \\
\hline Constant (z) & $\begin{array}{c}1980.25 * * * \\
(108.62)\end{array}$ & $\begin{array}{c}716.32 \text { *** } \\
(95.26)\end{array}$ & $\begin{array}{l}-1539.27 \\
(1066.26)\end{array}$ & $\begin{array}{l}-1242.15 \\
(803.44)\end{array}$ & $\begin{array}{c}1377.68 \\
(1110.203)\end{array}$ & $\begin{array}{c}1222.89 \\
(1004.625)\end{array}$ & $\begin{array}{l}-2157.58 \\
(2290.66)\end{array}$ & $\begin{array}{l}-264.25 \\
(1956.6)\end{array}$ \\
\hline Sigma $(\sigma)$ & $\begin{array}{c}3258.80 * * * \\
(126.81)\end{array}$ & $\begin{array}{c}2278.2 * * * \\
(98.14)\end{array}$ & $\begin{array}{l}2924.75 * * * * \\
(121.557)\end{array}$ & $\begin{array}{l}1975.98 * * * \\
(91.71)\end{array}$ & $\begin{array}{c}2298.04 * * * \\
(180.96)\end{array}$ & $\begin{array}{c}1986.09 * * * \\
(166.389)\end{array}$ & $\begin{array}{c}2172.49 * * * \\
(183.58)\end{array}$ & $\begin{array}{c}1812.17 * * * \\
(159.96)\end{array}$ \\
\hline Position of valuation question & & & 261.65 & $258.94^{*}$ & $\begin{array}{l}82.92 \\
(312.88)\end{array}$ & $\begin{array}{l}-55.37 \\
(286.110)\end{array}$ & $\begin{array}{l}259.92 \\
(344.38)\end{array}$ & 170.12 \\
\hline Age & & & $\begin{array}{c}-58.34 * * * * \\
(12.09)\end{array}$ & $\begin{array}{c}-34.14 * * * * \\
(9.04)\end{array}$ & & & $\begin{array}{c}-21.72 \\
(19.8)\end{array}$ & $\begin{array}{r}-6.55 \\
(17.63)\end{array}$ \\
\hline Gender & & & $\begin{array}{l}377.01 \\
(265.37)\end{array}$ & $\begin{array}{l}354.21 * \\
(191.44)\end{array}$ & & & $\begin{array}{l}986.81 * * \\
(449.12)\end{array}$ & $\begin{array}{l}927.01 \text { ** } \\
(396.19)\end{array}$ \\
\hline Education & & & 1311.24 & $\begin{array}{l}477.96 \\
(68169)\end{array}$ & & & $\begin{array}{l}1893.79 \\
0\end{array}$ & $\begin{array}{l}352.99 \\
0\end{array}$ \\
\hline House owners & & & 757.12 & 214.02 & & & $594.48^{*}$ & 370.03 \\
\hline House owners & & & $(216.56)$ & (156.45) & & & $(352.24)$ & $(310.94)$ \\
\hline Years in present house & & & $\begin{array}{c}142.46 * * * \\
(34.88)\end{array}$ & $\begin{array}{l}87.98 * * * \\
(25.09)\end{array}$ & & & $\begin{array}{l}92.45 * \\
(54.5)\end{array}$ & $\begin{array}{l}77.36 \\
(49.24)\end{array}$ \\
\hline Years in South Lunzu & & & $\begin{array}{l}-44.89 * \\
(23.88)\end{array}$ & $\begin{array}{l}-22.83 \\
(17.60)\end{array}$ & & & $\begin{array}{l}-58.28 \\
(38.30)\end{array}$ & $\begin{array}{c}-87.64 * * \\
(41.55)\end{array}$ \\
\hline Employment status & & & $\begin{array}{l}-53.27 \\
(232.91)\end{array}$ & $\begin{array}{c}138.18 \\
(170.52)\end{array}$ & & & $\begin{array}{c}77.47 \\
(452.41)\end{array}$ & $\begin{array}{l}-256.77 \\
(397.63)\end{array}$ \\
\hline Household income & & & $\begin{array}{c}0.022 * * * \\
(0.00)\end{array}$ & $\begin{array}{c}0.01 * * * \\
(0.00)\end{array}$ & & & $\begin{array}{c}0.01 \text { *** } \\
(0.00)\end{array}$ & $\begin{array}{c}0.01 * * * \\
(0.00)\end{array}$ \\
\hline Walking with bag of waste & & & & & $\begin{array}{l}-1863.72 * * * \\
(577.1)\end{array}$ & $\begin{array}{l}-1260.14 * * \\
(499.59)\end{array}$ & $\begin{array}{l}-1492.36 \text { ** } \\
(639.61)\end{array}$ & $\begin{array}{l}-904.69^{*} \\
(535.65)\end{array}$ \\
\hline Satisfaction for SWM & & & & & $\begin{array}{c}1855.27^{* *} \\
(819.34)\end{array}$ & $\begin{array}{l}428.26 \\
(734)\end{array}$ & $\begin{array}{l}1842.09^{*} \\
(985.44)\end{array}$ & $\begin{array}{l}489.92 \\
(847.73)\end{array}$ \\
\hline & & & & & $\begin{array}{l}(819.34) \\
1364.82\end{array}$ & $\begin{array}{c}(734) \\
-396.32\end{array}$ & $\begin{array}{c}(985.44) \\
678.48\end{array}$ & $\begin{array}{l}(847.73) \\
-1144.08\end{array}$ \\
\hline Ranking for SWM & & & & & $(1089.09)$ & (1077.03) & (1130.01) & $(1096.23)$ \\
\hline$n$ & 1256 & 1256 & 1054 & 1054 & 297 & 297 & 242 & 242 \\
\hline
\end{tabular}

Robust standard errors in parenthesis, ${ }^{* * *} p<0.01,{ }^{* *} p<0.05,{ }^{*} p<0.1$. 
Odd numbered columns are for the five minute walk scenario and even numbered columns are for the 30 min walk scenario. The table also illustrates how personal and household traits along with environmental variables influence WTP. Columns 1 and 2 represent the findings from the base model where WTP was calculated without any covariates. Columns 2 and 4 include the respondent and households' characteristics. Columns 5 and 6 include covariates related to the present practices in solid waste management. In Columns 7 and 8 all variables were taken into consideration.

As shown in Columns 3-8 was a difference in WTP depending on the placement of the questions: when placed later in the questionnaire, WTP was K2139 for scenario one and 1780 for scenario two. When the valuation question was placed first, WTP was K946 for scenario one and K1139 for scenario two.

For a unit increase in age, there was a decrease in WTP of -58 in scenario one and -34 in scenario two, with both decreases being significant (Columns 3 and 4) when only demographic information is included in the model. The unit decrease in WTP changed to -22 and -7 for scenario one and two respectively when all variables are included (Columns 7 and 8).

Women had a higher WTP than men in all instances of the model (all columns). A difference in WTP of K986 was obtained for scenario one (Column 7) and K927 for scenario two. The difference in both scenarios was found to be significant.

For each unit increase in the number of years a family had stayed in South Lunzu, there was an increase in WTP of K142 and K88 for scenario one and scenario two respectively (Column 3 and 4). However, for every unit increase in the number of years a family had stayed in South Lunzu, there was a decrease in WTP of -45 and -23 for scenario one and scenario two respectively (Column 3 and 4).

Columns 5 and 6 indicate that those who were satisfied with the present practice of solid waste management had a higher WTP that those unsatisfied with a difference of K1855 (significant at 95 percent confidence) and K428 for scenario one and scenario two respectively. Sixty-one households were not satisfied with the present practice and 1172 respondents were satisfied. Thus, the disparity in WTP can be attributed to the number of respondents that were satisfied being greater than those unsatisfied.

The key differences between the two solid waste collection programs was the time taken to transport waste to the disposal site and the frequency at which waste is taken to the disposal site. Respondents had a higher WTP for the scenario with a shorter walking time despite having their waste collected once a week.

Placing the valuation question before all other questions resulted in a lower WTP value compared to placing it after obtaining the respondents' perceptions on waste management. This result is an indication that other questions influence the respondent's choices. A pilot implementation would be required to select the position that gives the most accurate willingness to pay value.

Details of the differences in WTP across social groups within the sample are in Appendix B. Key differences to note were those within the gender groups, education levels, house ownership, and employment. Table 5 highlights some of the key differences in WTP between groups from the sample. 
Table 5. Willingness to pay values.

\begin{tabular}{|c|c|c|c|}
\hline \multirow{4}{*}{$\begin{array}{c}\text { Base WTP } \\
n\end{array}$} & \multicolumn{2}{|c|}{ Average WTP } & \multirow[t]{4}{*}{$p$-Value } \\
\hline & 5 min walk & 30 min walk & \\
\hline & K1980 & K716 & \\
\hline & 1256 & 1256 & \\
\hline & Q Position 1 & Q Position 2 & \\
\hline WTP for 5 min walk & K1780 & K2139 & 0.0087 \\
\hline WTP for $30 \mathrm{~min}$ walk & K946 & K1139 & 0.1161 \\
\hline \multirow[t]{2}{*}{$n$} & 132 & 110 & \\
\hline & Men & Women & \\
\hline WTP for 5 min walk & K1567 & K2394 & 0 \\
\hline WTP for 30 min walk & K600 & K1555 & 0 \\
\hline \multirow[t]{2}{*}{$n$} & 132 & 110 & \\
\hline & Rental & Owner & \\
\hline WTP for 5 min walk & K1725 & K2219 & 0.0003 \\
\hline WTP for 30 min walk & K976 & K1107 & 0.2904 \\
\hline \multirow[t]{2}{*}{$n$} & 135 & 107 & \\
\hline & No Education & Educated & \\
\hline WTP for 5 min walk & $\mathrm{K}-287$ & K1971 & 0.0002 \\
\hline WTP for 30 min walk & K150 & K1045 & 0.108 \\
\hline$n$ & 3 & 239 & \\
\hline & Unemployed & Employed & \\
\hline WTP for 5 min walk & 1927 & 1949 & 0.8878 \\
\hline WTP for 30 min walk & 1297 & 937 & 0.0094 \\
\hline$n$ & 65 & 177 & \\
\hline
\end{tabular}

Educated respondents had a higher willingness to pay than those without any form of education. Respondents without any formal education had a negative WTP, which suggests that they have an intention of receiving money, and which may indicate they were unclear about the bidding system or that they were actually seeking payment. Those with tertiary education had a willingness to pay of K2210 to walk five minutes to the disposal point and K1233 to walk $30 \mathrm{~min}$, and those without tertiary education had WTP of K1770 for the five minute walk scenario and K905 for the 30 min walk scenario.

In the five minute walk scenario, those who were employed had a WTP of K1949 which was higher than the WTP of K1927 that those who were unemployed offered, although the difference was only K22 and not significant. However, the difference rose up to K359 with those unemployed having a higher WTP of K1297 and those employed having a lower WTP of K937. It should be noted as well, that the baseline walking time was nearly seven minutes (Table 3). Thus, the willingness to pay as well as an additional amount of time to access proper solid waste disposal is a significant finding. In the distribution of WTP across forms of employment, employees of non-governmental organizations had the highest average WTP, seconded by students. Government employees had the lowest WTP among the forms of employment considered. The trend in Figure 2 suggests a possible correlation between employers, household income and WTP values. 


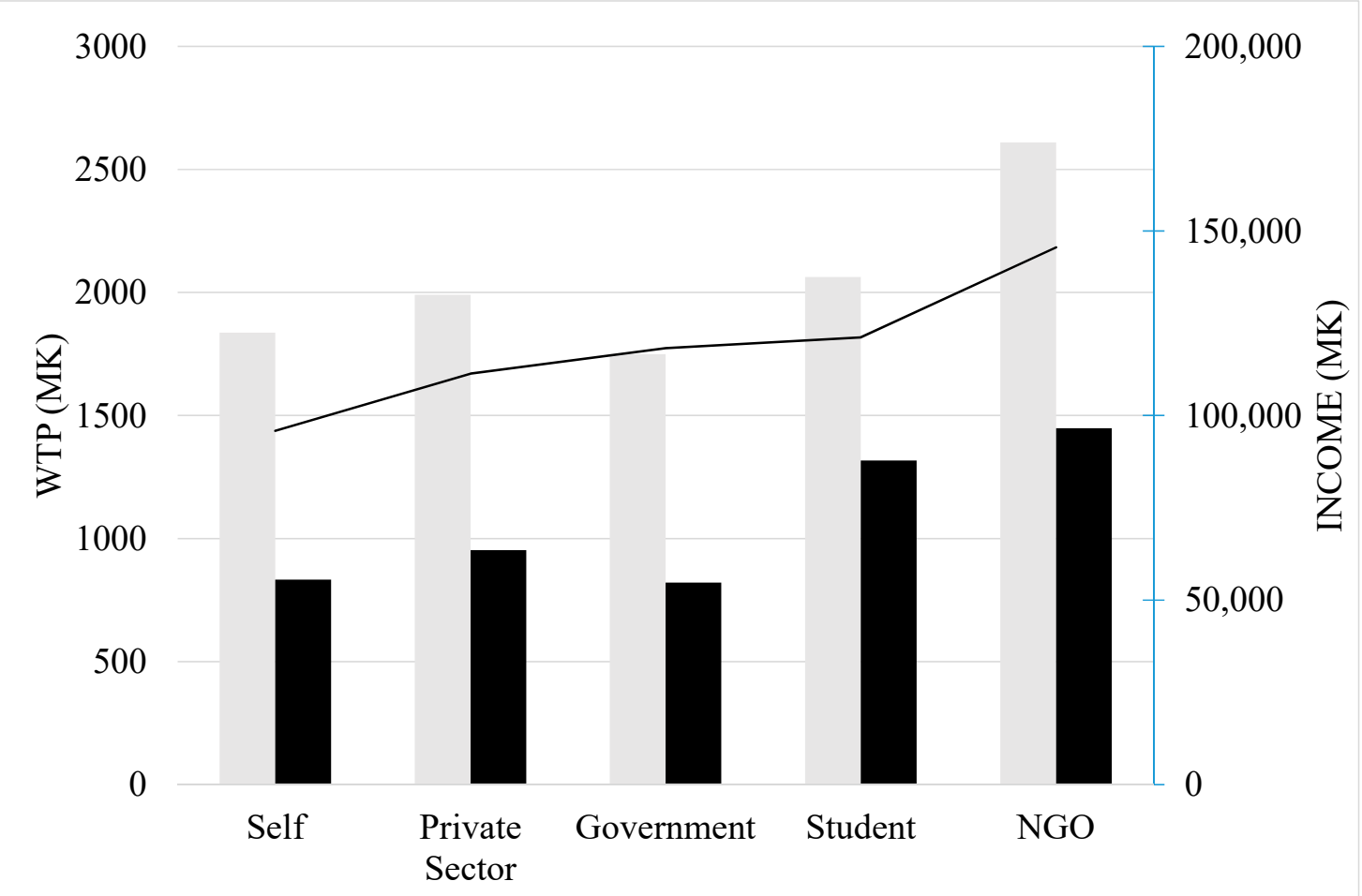

WTP for walking 5 minutes - WTP for walking 30 minutes - Income

Figure 2. Willingness to pay (WTP) variation with income and place of employment.

\section{Discussion}

A WTP value of K716 per month for the 30 min walk scenario shows that there is a potential of raising up to K8786 per household per year for solid waste collection in South Lunzu. WTP for the five minute walk scenario presents an opportunity to raise up to K23,763 per household annually for solid waste collection. The population of South Lunzu was 38,966 in 2012 (UN-Habitat 2012), translating to approximately 7640 households and probably more than 9000 by 2018 (official statistics are not available). Thus, an annual revenue of between K67,124,428 and K181,549,320 could be collected if all households in South Lunzu were to participate (based on a population of 38,966). This not only presents an opportunity for financing solid waste collection, but also business creation and employment within the solid waste value chain.

Furthermore, the residents of South Lunzu are willing to segregate their waste provided the incentives are in place. This willingness presents an opportunity to reduce the quantity of waste that arrives at the dump site, provided the necessary treatment technologies and systems are in place (e.g., composting, recycling, etc.). However, for the benefits of these model systems to be realized, a comprehensive study would have to be carried out to identify the composition of the solid waste.

Out of the households, $55.89 \%$ were found to be willing participants in solid waste collection. While it is true that over $44 \%$ of respondents were not willing to contribute (WTP $=0$ ), the average salary among respondents was about $\$ 150 /$ month (Table 3 ) and the estimated WTP values ranged up to $2 \%$ of the monthly income: a non-significant portion of a very low income. Collectively the households willing to participate generate $42 \%$ of the waste generated by the sampled households; in the short term, a reduction in solid waste would be expected to improve the quality and aesthetics of the local environment, and in the long term, cause a trickle-down effect, ideally encouraging non-participants to join.

Women had a higher WTP than men, enforcing the oft-held but rarely quantified notion that women have a higher sensitivity to their environment than men. In essence, this would highlight a 
need to involve more women in the management of solid waste as this suggests potentially higher commitment towards living in clean surroundings. However, this can only be verified through a pilot implementation.

The difference in the WTP amounts between those who had stayed in the same house for longer and those who had changed houses could be because of the potential change in the household environment when the family moves to a new house. Those who have stayed in the same house for long may expect to stay there longer and thus are more concerned about their home. Those who have not stayed as long in South Lunzu are perhaps more transient and may be intending to move from their present house in South Lunzu, resulting in lower WTP. We found no correlation between the current disposal practices and the WTP values.

The significant difference in WTP based on the position of the valuation question indicates that the design of a WTP survey should take into consideration the structure of the questionnaire itself. A pilot trial would be required in order to ascertain which position of the question in the questionnaire obtains more accurate willingness to pay. This symbolizes the tradeoff that the people are willing to make in order to improve solid waste management in the area.

\section{Conclusions}

Our results indicate that there is a willingness to pay for improving solid waste collection in South Lunzu. However, the amount of money the people were willing to pay depended on several factors. Increasing income led to higher WTP values, which is to be expected. Older people had a lower WTP compared to younger people. Respondents who had some education had a positive WTP and those without any formal education had a negative WTP. Such variations in WTP show that the social characteristics of respondents as well as demographic characteristics are critical in revenue generation from waste collection. Given the variation, the lowest acceptable WTP value would likely have to be piloted to ensure the broadest rate of acceptance.

When designing the solid waste collection systems, walking distance is a crucial factor in its success. The higher WTP for walking five minutes to the disposal point signifies a preference for short distances.

There is potential to improve solid waste management through improvements in solid waste collection at the community level through community managed solid waste collection schemes. Despite this, further campaigns would have to be developed and implemented to gain collective support from all community members, as well as to increase awareness of all individual's roles.

The impact of environmental framing and the position of the valuation question should also be taken into consideration. Other questions may influence the respondents to give a higher or lower WTP and result in biased responses. Overall, varying the position of the WTP question is likely to identify possible influences of preceding questions on WTP. A pilot implementation of the presented hypothetical scenarios coupled with a choice experiment would identify the position of the valuation question that more accurately estimates the WTP. Practically, the pilot should be coupled with an environmental awareness campaign, since the messaging appears to have an impact on the actual WTP value.

At least $56 \%$ of households gave a "yes" response for scenario with a five minute walking time (scenario one) and 38\% said "yes" to walking $30 \mathrm{~min}$ (scenario two). Projecting this finding to the population of South Lunzu, 4263 households would agree to participate in scenario one and 2926 households would participate in scenario one. An annual total of K101,301,669 could be realized if scenario one was to be implemented and $\mathrm{K} 25,707,602$ if scenario two was to be implemented. This represents a potential source of finance that could be used to improve solid waste management, as well as other community amenities such as drainage.

The findings also imply that policy should consider expanding the role of waste management from the city council to the local communities. In this case, the city could provide centrally located transfer stations and require that local communities mobilize themselves to raise resources for waste 
collection to the transfer station. Under this new strategy, the city would facilitate the formation of community-based waste management committees that would enforce waste separation and community hygiene on the council's behalf.

A pilot implementation is needed in order to ascertain the actual WTP. This pilot implementation would also help identify the position of the valuation question in the questionnaire that accurately estimated the actual WTP. Among the factors to be included in the pilot would be a test for source separation of solid waste and the impact of distance on WTP.

City councils that are unable to provide city-wide services should delegate their waste collection responsibilities to communities by facilitating the formation of community management committees that will collect solid waste and payments. This system would enable solid waste collection even in hard to reach areas where there is no road access.

Future work making use of dichotomous choice contingent valuation should pay careful attention to the position of valuation question relative to other questions. Since the position of the question that best estimates WTP is not yet known, researchers should randomize the position of the WTP question in the questionnaires.

Author Contributions: The work was conceived and designed by H.N. and E.T.; the data was collected by H.N.; the analysis was conducted by H.N.; the paper was written by E.T. and H.N.

Funding: This research was supported by Eawag-Swiss Federal Institute of Aquatic Science and Technology.

Conflicts of Interest: The authors declare no conflicts of interest.

\section{Appendix A.}

Questionnaire A (0)

\begin{tabular}{|c|c|c|c|}
\hline & Questions & Code & Responses \\
\hline A & Valuation & & \\
\hline $\mathrm{A} 1$ & $\begin{array}{l}\text { Scenario 1: Imagine if there was a community managed } \\
\text { service to collect waste every week, from the road nearest to } \\
\text { your house where you would walk a maximum of } 5 \text { min to } \\
\text { that road while carrying waste containers once a week on the } \\
\text { collection day. Participation in this would require that you put } \\
\text { plastics, food waste, glass, metals and yard waste in separate } \\
\text { plastic bags to allow recycling. For this to work, you would } \\
\text { have to pay a monthly fee to a community managed account. } \\
\text { The money from this account will be used to finance the waste } \\
\text { collection service. The monthly fee to pay is } \\
\text { MWK.......................... Would you participate, keeping in } \\
\text { mind that this will reduce the amount of money available for } \\
\text { other uses? }\end{array}$ & 0 & No \\
\hline A2 & $\begin{array}{l}\text { If the amount to pay was MWK } \ldots \ldots \ldots \ldots \ldots \ldots \text {, would } \\
\text { you participate? }\end{array}$ & $\begin{array}{l}0 \\
1\end{array}$ & $\begin{array}{l}\text { No } \\
\text { Yes }\end{array}$ \\
\hline
\end{tabular}




\begin{tabular}{|c|c|c|c|}
\hline & Questions & Code & Responses \\
\hline $\mathbf{A}$ & Valuation & & \\
\hline A4 & $\begin{array}{l}\text { Scenario 2: Imagine if there was a different community } \\
\text { managed service to collect waste every week from a road } \\
\text { junction near your house where you would walk a maximum } \\
\text { of } 30 \text { min when carrying waste from your house to that place. } \\
\text { Participation in this would also require you to put plastics, } \\
\text { food waste, glass, metals and yard waste in separate plastic } \\
\text { bags for recycling. For this to work, you would have to make } \\
\text { a monthly contribution to a community managed account. } \\
\text { The money will be used to finance the operation of the solid } \\
\text { waste collection system. The amount of money you have to } \\
\text { pay every month is MWK...................... Would you } \\
\text { participate, keeping in mind that this will reduce the amount } \\
\text { of money available for other uses? }\end{array}$ & 1 & Yes \\
\hline \multirow{2}{*}{ A5 } & If the amount to pay was MWK $\ldots \ldots \ldots \ldots \ldots \ldots$, would & 0 & No \\
\hline & you participate? & 1 & Yes \\
\hline B & Demographics & & \\
\hline B0 & Respondent Number & & \\
\hline B1 & Date of Interview & & \\
\hline B2 & Area of residence & & \\
\hline B3 & Respondent Age & & \\
\hline \multirow{2}{*}{ B4 } & \multirow{2}{*}{ Respondent Sex } & 0 & Male \\
\hline & & 1 & Female \\
\hline \multirow{4}{*}{ B5 } & \multirow{4}{*}{ Highest level of education } & 0 & No education \\
\hline & & 1 & Primary education \\
\hline & & 2 & Secondary education \\
\hline & & 3 & Tertiary education \\
\hline \multirow{9}{*}{ B6 } & & 0 & Male head of $\mathrm{HH}$ \\
\hline & & 1 & Female head of $\mathrm{HH}$ \\
\hline & & 2 & Spouse of head of $\mathrm{HH}$ \\
\hline & & 3 & Son of head of $\mathrm{HH}$ \\
\hline & What is your position in the household & 4 & Daughter of head of $\mathrm{HH}$ \\
\hline & & 5 & Mother of head of $\mathrm{HH}$ \\
\hline & & 6 & Father of head of $\mathrm{HH}$ \\
\hline & & 7 & Other female \\
\hline & & 8 & Other male \\
\hline \multirow{2}{*}{ B7 } & \multirow{2}{*}{ House ownership status } & 0 & Owner \\
\hline & & 1 & Rental \\
\hline B8 & How many people live in this house? & & \\
\hline B9 & How long have you lived in South Lunzu (Machinjiri)? & & \\
\hline B10 & How long have you lived in this house? & & \\
\hline \multirow{7}{*}{ B11 } & \multirow{7}{*}{ Employment type } & 0 & Unemployed \\
\hline & & 1 & Self employed \\
\hline & & 2 & Government employee \\
\hline & & 3 & Private sector \\
\hline & & 4 & Non-governmental Organization \\
\hline & & 5 & Student \\
\hline & & 6 & Other (Specify): ... \\
\hline \multirow{11}{*}{ B12 } & \multirow{11}{*}{$\begin{array}{l}\text { In which income bracket does your monthly household } \\
\text { income fall? }\end{array}$} & & Less than $\mathrm{K} 5,000$ \\
\hline & & & $\mathrm{K} 5,001$ to $\mathrm{K} 10,000$ \\
\hline & & & $\mathrm{K} 10,001$ to $\mathrm{K} 15,000$ \\
\hline & & & $\mathrm{K} 15,001$ to $\mathrm{K} 20,000$ \\
\hline & & & $\mathrm{K} 20,001$ to $\mathrm{K} 50,000$ \\
\hline & & & $\mathrm{K} 50,001$ to $\mathrm{K} 80,000$ \\
\hline & & & $\mathrm{K} 80,001$ to $\mathrm{K} 120,000$ \\
\hline & & & $\mathrm{K} 120,001$ to $\mathrm{K} 150,000$ \\
\hline & & & $\mathrm{K} 150,001$ to $\mathrm{K} 200,000$ \\
\hline & & & $\mathrm{K} 200,001$ to $\mathrm{K} 250,000$ \\
\hline & & & More than $\mathrm{K} 250,001$ \\
\hline C & Present solid waste management practice & & \\
\hline $\mathrm{C} 1$ & How many 2L basins of waste do you produce per day? & & \\
\hline \multirow{10}{*}{$\mathrm{C} 2$} & \multirow{10}{*}{ Where do you dump plastic waste? } & 0 & Rubbish pit \\
\hline & & 1 & Road \\
\hline & & 2 & Open Dump \\
\hline & & 3 & Sell to recyclers \\
\hline & & 4 & Burning \\
\hline & & 5 & Landscaping \\
\hline & & 6 & No plastic waste \\
\hline & & 7 & Don't know \\
\hline & & 8 & Other (Specify): ... \\
\hline & & & $\cdots \cdots \cdots \cdots \cdots$ \\
\hline
\end{tabular}




\begin{tabular}{|c|c|c|c|}
\hline & Questions & Code & Responses \\
\hline A & Valuation & & \\
\hline \multirow{11}{*}{ C3 } & \multirow{11}{*}{ Where do you dump glass waste? } & 0 & Rubbish pit \\
\hline & & 1 & Road \\
\hline & & 2 & Open Dump \\
\hline & & 3 & Sell to recyclers \\
\hline & & 4 & Burning \\
\hline & & 5 & Landscaping \\
\hline & & 6 & Pit latrine \\
\hline & & 7 & No glass waste \\
\hline & & 8 & Don't know \\
\hline & & 9 & Other (Specify): ............ \\
\hline & & & $\ldots \ldots \ldots \ldots \ldots \ldots \ldots$ \\
\hline \multirow{11}{*}{$\mathrm{C} 4$} & \multirow{11}{*}{ Where do you dump metal waste? } & 0 & Rubbish pit \\
\hline & & 1 & Road \\
\hline & & 2 & Open Dump \\
\hline & & 3 & Sell to recyclers \\
\hline & & 4 & Burning \\
\hline & & 5 & Landscaping \\
\hline & & 6 & Pit latrine \\
\hline & & 7 & No metal waste \\
\hline & & 8 & Don't know \\
\hline & & 9 & Other (Specify) $\ldots \ldots \ldots \ldots \ldots$ \\
\hline & & & $\cdots \cdots \cdots \cdots \cdots \cdots \cdots \cdots$ \\
\hline \multirow{12}{*}{ C5 } & \multirow{12}{*}{ Where do you dump of food waste? } & 0 & R̈ubbish pit \\
\hline & & 1 & Road \\
\hline & & 2 & Open Dump \\
\hline & & 3 & Sell to recyclers \\
\hline & & 4 & Burning \\
\hline & & 5 & Garden Manure \\
\hline & & 6 & Fed to animals \\
\hline & & 7 & Toilet \\
\hline & & 8 & No food waste \\
\hline & & 9 & Don't know \\
\hline & & 10 & Other (Specify): $\ldots \ldots \ldots \ldots \ldots$ \\
\hline & & & $\ldots \ldots \ldots \ldots \ldots \ldots \ldots \ldots$ \\
\hline \multirow{12}{*}{ C6 } & \multirow{12}{*}{ Where do you dump yard waste? } & 0 & R̈ubbish pit \\
\hline & & 1 & Road \\
\hline & & 2 & Open Dump \\
\hline & & 3 & Sell to recyclers \\
\hline & & 4 & Burning \\
\hline & & 5 & Garden Manure \\
\hline & & 6 & Fed to animals \\
\hline & & 7 & Toilet \\
\hline & & 8 & No yard waste \\
\hline & & 9 & Don't know \\
\hline & & 10 & Other (Specify): . . . . . . . . \\
\hline & & & $\ldots \ldots \ldots$ \\
\hline
\end{tabular}

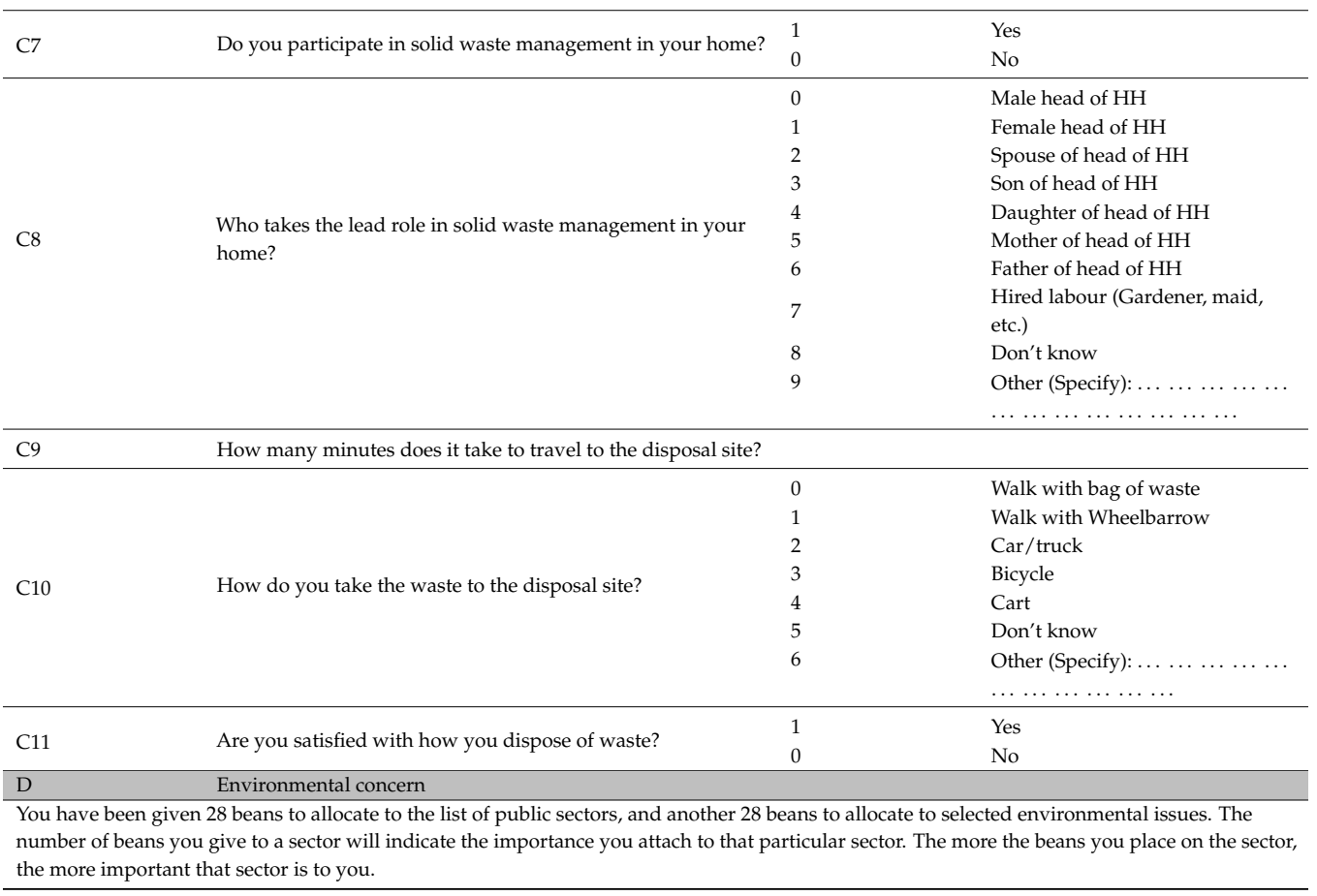




\begin{tabular}{|c|c|c|}
\hline & Questions & Responses \\
\hline A & Valuation & \\
\hline \multirow{9}{*}{ D1 } & \multirow{9}{*}{$\begin{array}{l}\text { From the following list which sector of public policy deserves } \\
\text { the most attention? Indicate the level of attention as instructed } \\
\text { above. }\end{array}$} & Public Education \\
\hline & & The Natural Environment \\
\hline & & Crime prevention \\
\hline & & Housing \\
\hline & & Unemployment and Poverty \\
\hline & & Public Health services \\
\hline & & National Defence \\
\hline & & Other (Specify) $\ldots \ldots \ldots \ldots \ldots$ \\
\hline & & $\ldots \ldots \ldots \ldots \ldots \ldots \ldots \ldots$ \\
\hline \multirow{9}{*}{ D2 } & \multirow{9}{*}{$\begin{array}{l}\text { Among the following Environmental issues, which of these } \\
\text { deserves the most attention? Indicate the level of attention as } \\
\text { instructed above. }\end{array}$} & Ẅater Pollution \\
\hline & & Air Pollution \\
\hline & & Deforestation \\
\hline & & Soil Erosion \\
\hline & & Solid waste management \\
\hline & & Loss of biodiversity \\
\hline & & Climate change \\
\hline & & Other (Specify) $\ldots \ldots \ldots \ldots \ldots$ \\
\hline & & $\ldots \ldots \ldots \ldots \ldots \ldots \ldots \ldots \ldots$ \\
\hline
\end{tabular}

\section{Questionnaire B (1)}

\begin{tabular}{|c|c|c|c|}
\hline & Question & Code & Response \\
\hline $\mathrm{C}$ & Present solid waste management practice & & \\
\hline $\mathrm{C} 1$ & $\begin{array}{l}\text { How many } 2 \mathrm{~L} \text { basins of waste do you produce } \\
\text { per day? }\end{array}$ & & \\
\hline \multirow{10}{*}{$\mathrm{C} 2$} & \multirow{10}{*}{ Where do you dump plastic waste? } & 0 & Rubbish pit \\
\hline & & 1 & Road \\
\hline & & 2 & Open Dump \\
\hline & & 3 & Sell to recyclers \\
\hline & & 4 & Burning \\
\hline & & 5 & Landscaping \\
\hline & & 6 & No plastic waste \\
\hline & & 7 & Don't know \\
\hline & & 8 & Other (Specify) $\ldots \ldots \ldots \ldots \ldots$ \\
\hline & & & $\ldots \ldots \ldots \ldots \ldots \ldots \ldots \ldots$ \\
\hline \multirow{11}{*}{$\mathrm{C} 3$} & \multirow{11}{*}{ Where do you dump glass waste? } & 0 & ஷ̈ubbish pit \\
\hline & & 1 & Road \\
\hline & & 2 & Open Dump \\
\hline & & 3 & Sell to recyclers \\
\hline & & 4 & Burning \\
\hline & & 5 & Landscaping \\
\hline & & 6 & Pit latrine \\
\hline & & 7 & No glass waste \\
\hline & & 8 & Don't know \\
\hline & & 9 & Other (Specify) $\ldots \ldots \ldots \ldots \ldots$ \\
\hline & & & $\ldots \ldots \ldots \ldots \ldots \ldots \ldots \ldots$ \\
\hline \multirow{11}{*}{$\mathrm{C} 4$} & \multirow{11}{*}{ Where do you dump metal waste? } & 0 & R̈ubbish pit \\
\hline & & 1 & Road \\
\hline & & 2 & Open Dump \\
\hline & & 3 & Sell to recyclers \\
\hline & & 4 & Burning \\
\hline & & 5 & Landscaping \\
\hline & & 6 & Pit latrine \\
\hline & & 7 & No metal waste \\
\hline & & 8 & Don't know \\
\hline & & 9 & Other (Specify) $\ldots \ldots \ldots \ldots \ldots$ \\
\hline & & & $\ldots \ldots \ldots \ldots \ldots \ldots$ \\
\hline
\end{tabular}




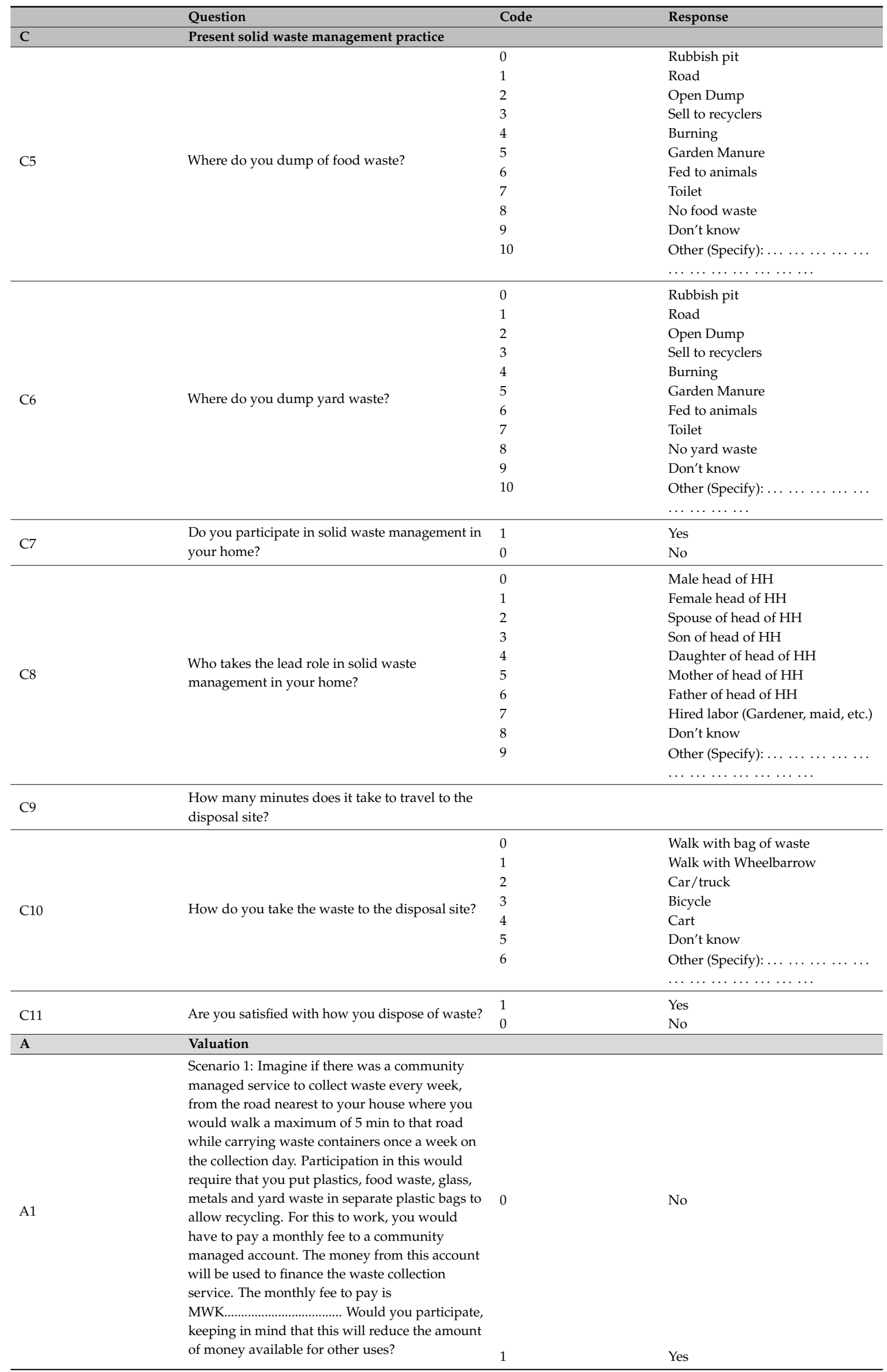




\begin{tabular}{|c|c|c|c|}
\hline & Question & Code & Response \\
\hline C & Present solid waste management practice & & \\
\hline \multirow{12}{*}{ C5 } & \multirow{12}{*}{ Where do you dump of food waste? } & 0 & Rubbish pit \\
\hline & & 1 & Road \\
\hline & & 2 & Open Dump \\
\hline & & 3 & Sell to recyclers \\
\hline & & 4 & Burning \\
\hline & & 5 & Garden Manure \\
\hline & & 6 & Fed to animals \\
\hline & & 7 & Toilet \\
\hline & & 8 & No food waste \\
\hline & & 9 & Don't know \\
\hline & & 10 & Other (Specify) $\ldots \ldots \ldots \ldots \ldots$ \\
\hline & & & $\ldots \ldots \ldots \ldots \ldots \ldots \ldots \ldots$ \\
\hline \multirow{12}{*}{ C6 } & \multirow{12}{*}{ Where do you dump yard waste? } & 0 & Rüubbish pit \\
\hline & & 1 & Road \\
\hline & & 2 & Open Dump \\
\hline & & 3 & Sell to recyclers \\
\hline & & 4 & Burning \\
\hline & & 5 & Garden Manure \\
\hline & & 6 & Fed to animals \\
\hline & & 7 & Toilet \\
\hline & & 8 & No yard waste \\
\hline & & 9 & Don't know \\
\hline & & 10 & Other (Specify) $\ldots \ldots \ldots \ldots \ldots$ \\
\hline & & & $\ldots \ldots \ldots \ldots \ldots \ldots$ \\
\hline \multirow{2}{*}{$\mathrm{C} 7$} & \multirow{2}{*}{$\begin{array}{l}\text { Do you participate in solid waste management in } \\
\text { your home? }\end{array}$} & 1 & Yes \\
\hline & & 0 & No \\
\hline \multirow{11}{*}{$\mathrm{C} 8$} & \multirow{11}{*}{$\begin{array}{l}\text { Who takes the lead role in solid waste } \\
\text { management in your home? }\end{array}$} & 0 & Male head of $\mathrm{HH}$ \\
\hline & & 1 & Female head of HH \\
\hline & & 2 & Spouse of head of $\mathrm{HH}$ \\
\hline & & 3 & Son of head of $\mathrm{HH}$ \\
\hline & & 4 & Daughter of head of $\mathrm{HH}$ \\
\hline & & 5 & Mother of head of $\mathrm{HH}$ \\
\hline & & 6 & Father of head of $\mathrm{HH}$ \\
\hline & & 7 & Hired labor (Gardener, maid, etc.) \\
\hline & & 8 & Don't know \\
\hline & & 9 & Other (Specify): . . . . . . . . . \\
\hline & & & $\ldots \ldots \ldots \ldots \ldots$ \\
\hline C9 & $\begin{array}{l}\text { How many minutes does it take to travel to the } \\
\text { disposal site? }\end{array}$ & & \\
\hline \multirow{8}{*}{$\mathrm{C} 10$} & \multirow{8}{*}{ How do you take the waste to the disposal site? } & 0 & Walk with bag of waste \\
\hline & & 1 & Walk with Wheelbarrow \\
\hline & & 2 & Car/truck \\
\hline & & 3 & Bicycle \\
\hline & & 4 & Cart \\
\hline & & 5 & Don't know \\
\hline & & 6 & Other (Specify): . . . . . . . . . \\
\hline & & & $\ldots \ldots \cdots \cdots \cdots \cdots$ \\
\hline \multirow{2}{*}{ C11 } & \multirow{2}{*}{ Are you satisfied with how you dispose of waste? } & 1 & Yes \\
\hline & & 0 & No \\
\hline $\mathbf{A}$ & Valuation & & \\
\hline A1 & $\begin{array}{l}\text { Scenario 1: Imagine if there was a community } \\
\text { managed service to collect waste every week, } \\
\text { from the road nearest to your house where you } \\
\text { would walk a maximum of } 5 \text { min to that road } \\
\text { while carrying waste containers once a week on } \\
\text { the collection day. Participation in this would } \\
\text { require that you put plastics, food waste, glass, } \\
\text { metals and yard waste in separate plastic bags to } \\
\text { allow recycling. For this to work, you would } \\
\text { have to pay a monthly fee to a community } \\
\text { managed account. The money from this account } \\
\text { will be used to finance the waste collection } \\
\text { service. The monthly fee to pay is } \\
\text { MWK................................ Would you participate, } \\
\text { keeping in mind that this will reduce the amount } \\
\text { of money available for other uses? }\end{array}$ & 0 & No \\
\hline
\end{tabular}




\begin{tabular}{|c|c|c|c|}
\hline & Question & Code & Response \\
\hline C & Present solid waste management practice & & \\
\hline \multirow[b]{2}{*}{ A2 } & If the amount to pay was MWK $\ldots \ldots \ldots \ldots \ldots$ & 0 & No \\
\hline & $\ldots$, would you participate? & 1 & Yes \\
\hline A4 & $\begin{array}{l}\text { Scenario 2: Imagine if there was a different } \\
\text { community managed service to collect waste } \\
\text { every week from a road junction near your house } \\
\text { where you would walk a maximum of } 30 \text { min } \\
\text { when carrying waste from your house to that } \\
\text { place. Participation in this would also require } \\
\text { you to put plastics, food waste, glass, metals and } \\
\text { yard waste in separate plastic bags for recycling. } \\
\text { For this to work, you would have to make a } \\
\text { monthly contribution to a community managed } \\
\text { account. The money will be used to finance the } \\
\text { operation of the solid waste collection system. } \\
\text { The amount of money you have to pay every } \\
\text { month is MWK........................... Would you } \\
\text { participate, keeping in mind that this will reduce } \\
\text { the amount of money available for other uses? }\end{array}$ & 1 & No \\
\hline \multirow{2}{*}{ A5 } & If the amount to pay was $\mathrm{K} \ldots \ldots \ldots \ldots \ldots$, & 0 & No \\
\hline & would you participate? & 1 & Yes \\
\hline B & Demographics & & \\
\hline B0 & Respondent Number & & \\
\hline B1 & Date of Interview & & \\
\hline B2 & Area of residence & & \\
\hline B3 & Respondent Age & & \\
\hline \multirow{2}{*}{ B4 } & \multirow{2}{*}{ Respondent Sex } & 0 & Male \\
\hline & & 1 & Female \\
\hline \multirow{4}{*}{ B5 } & \multirow{4}{*}{ Highest level of education } & 0 & No education \\
\hline & & 1 & Primary education \\
\hline & & 2 & Secondary education \\
\hline & & 3 & Tertiary education \\
\hline \multirow{9}{*}{ B6 } & \multirow{9}{*}{ What is your position in the household } & 0 & Male head of $\mathrm{HH}$ \\
\hline & & 1 & Female head of $\mathrm{HH}$ \\
\hline & & 2 & Spouse of head of $\mathrm{HH}$ \\
\hline & & 3 & Son of head of $\mathrm{HH}$ \\
\hline & & 4 & Daughter of head of $\mathrm{HH}$ \\
\hline & & 5 & Mother of head of $\mathrm{HH}$ \\
\hline & & 6 & Father of head of $\mathrm{HH}$ \\
\hline & & 7 & Other female \\
\hline & & 8 & Other male \\
\hline \multirow{2}{*}{ B7 } & & 0 & Owner \\
\hline & House ownership status & 1 & Rental \\
\hline B8 & How many people live in this house? & & \\
\hline B9 & $\begin{array}{l}\text { How long have you lived in South Lunzu } \\
\text { (Machinjiri)? }\end{array}$ & & \\
\hline B10 & How long have you lived in this house? & & \\
\hline \multirow{8}{*}{ B11 } & \multirow{8}{*}{ Employment type } & 0 & Unemployed \\
\hline & & 1 & Self employed \\
\hline & & 2 & Government employee \\
\hline & & 3 & Private sector \\
\hline & & 4 & Non-governmental Organization \\
\hline & & 5 & Student \\
\hline & & 6 & Other (Specify): $\ldots \ldots \ldots \ldots \ldots$ \\
\hline & & & $\ldots \ldots \ldots \ldots \ldots \ldots$ \\
\hline
\end{tabular}




\begin{tabular}{lll}
\hline & Question & Code \\
\hline C & Present solid waste management practice & Less than K5,000 \\
& & $\mathrm{K} 5,001$ to K10,000 \\
& & $\mathrm{K} 10,001$ to K15,000 \\
& & $\mathrm{K} 15,001$ to K20,000 \\
& & $\mathrm{K} 20,001$ to K50,000 \\
B12 & In which income bracket does your monthly & $\mathrm{K} 50,001$ to K80,000 \\
& houshold income fall? & $\mathrm{K} 80,001$ to K120,000 \\
& & $\mathrm{K} 120,001$ to K150,000 \\
& & $\mathrm{K} 150,001$ to K200,000 \\
& & $\mathrm{K} 200,001$ to K250,000 \\
\hline D & Environmental concern & More than K250,001 \\
\hline
\end{tabular}

You have been given 28 beans to allocate to the list of public sectors, and another 28 beans to allocate to selected environmental issues.

The number of beans you give to a sector will indicate the importance you attach to that particular sector. The more the beans you place on the sector, the more important that sector is to you.

Public Education

The Natural Environment

Crime prevention

Housing

From the following list which sector of public

Unemployment and Poverty policy deserves the most attention? Indicate the

Public Health services

Defense

Other (Specify) : . . . . . . . . .

$\ldots \ldots \ldots \ldots \ldots \ldots \ldots$

Water Pollution

Air Pollution

Deforestation

Among the following Environmental issues,

Soil Erosion

D2 which of these deserves the most attention?

Solid waste management

Indicate the level of attention as instructed above.

Loss of biodiversity

Climate change

Other (Specify) : . . . . . . . . .

$\ldots \ldots \ldots \ldots \ldots \ldots$

\section{Appendix B.}

Full model results

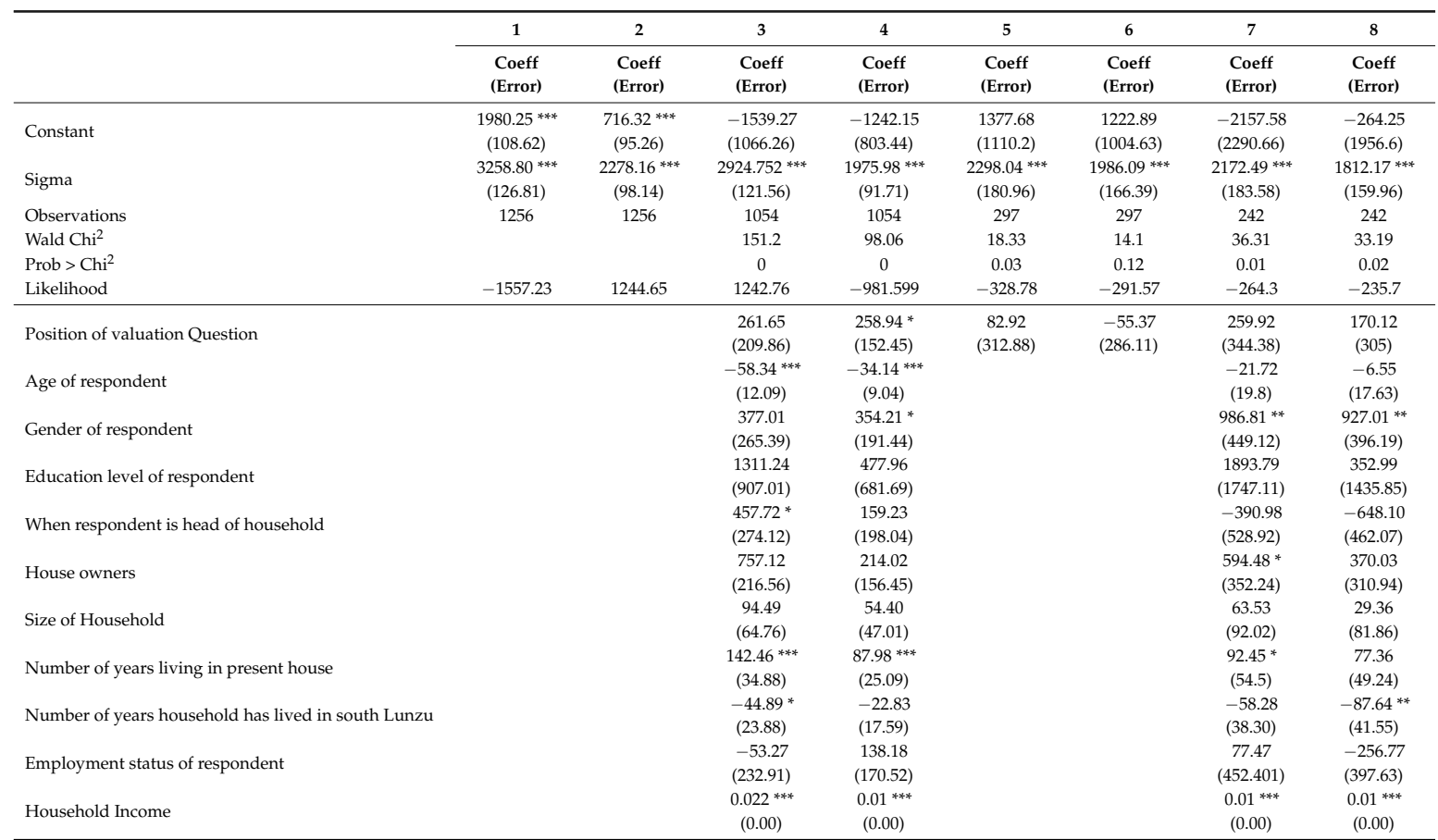




\begin{tabular}{|c|c|c|c|c|c|c|c|c|}
\hline & 1 & 2 & 3 & 4 & 5 & 6 & 7 & 8 \\
\hline & $\begin{array}{l}\text { Coeff } \\
\text { (Error) }\end{array}$ & $\begin{array}{l}\text { Coeff } \\
\text { (Error) }\end{array}$ & $\begin{array}{l}\text { Coeff } \\
\text { (Error) }\end{array}$ & $\begin{array}{l}\text { Coeff } \\
\text { (Error) }\end{array}$ & $\begin{array}{l}\text { Coeff } \\
\text { (Error) }\end{array}$ & $\begin{array}{l}\text { Coeff } \\
\text { (Error) }\end{array}$ & $\begin{array}{l}\text { Coeff } \\
\text { (Error) }\end{array}$ & $\begin{array}{l}\text { Coeff } \\
\text { (Error) }\end{array}$ \\
\hline Quantity of solid waste & & & & & $\begin{array}{c}60.21 \\
(178.77)\end{array}$ & $\begin{array}{c}91.93 \\
(160.5)\end{array}$ & $\begin{array}{c}-5.33 \\
(203.16)\end{array}$ & $\begin{array}{l}-109.05 \\
(181.28)\end{array}$ \\
\hline Waste Separation & & & & & $\begin{array}{l}-448.99 \\
(375.66)\end{array}$ & $\begin{array}{l}-183.91 \\
(343.67)\end{array}$ & $\begin{array}{l}-397.45 \\
(415.07)\end{array}$ & $\begin{array}{l}-185.33 \\
(369.81)\end{array}$ \\
\hline $\begin{array}{l}\text { Mode of transport used (walking with bag of waste vs } \\
\text { wheelbarrow) }\end{array}$ & & & & & $\begin{array}{l}-1863.72 * * * \\
(577.1)\end{array}$ & $\begin{array}{c}-1260.14^{* *} \\
(499.59)\end{array}$ & $\begin{array}{c}-1492.36^{* *} \\
(639.61)\end{array}$ & $\begin{array}{l}-904.69 * \\
(535.65)\end{array}$ \\
\hline $\begin{array}{l}\text { When respondent is also leader of solid waste } \\
\text { management }\end{array}$ & & & & & $\begin{array}{c}597.11 \\
(407.62)\end{array}$ & $\begin{array}{l}402.24 \\
(380.22)\end{array}$ & $\begin{array}{c}474.47 \\
(468.86)\end{array}$ & $\begin{array}{c}338.67 \\
(412.42)\end{array}$ \\
\hline Time taken to travel to present solid waste disposal site & & & & & $\begin{array}{l}-26.50 \\
(36.47)\end{array}$ & $\begin{array}{l}-29.77 \\
(34.27)\end{array}$ & $\begin{array}{c}3.93 \\
(42.58)\end{array}$ & $\begin{array}{l}-13.86 \\
(40.27)\end{array}$ \\
\hline $\begin{array}{l}\text { Satisfaction for present solid waste management } \\
\text { practices }\end{array}$ & & & & & $\begin{array}{c}1855.27^{* *} \\
(819.34)\end{array}$ & $\begin{array}{c}428.26 \\
(734)\end{array}$ & $\begin{array}{l}1842.09^{*} \\
(985.44)\end{array}$ & $\begin{array}{c}489.92 \\
(847.73)\end{array}$ \\
\hline Priority ranking for solid waste management & & & & & $\begin{array}{c}1364.82 \\
(1089.09)\end{array}$ & $\begin{array}{c}-396.32 \\
(1077.03)\end{array}$ & $\begin{array}{c}678.48 \\
(1130.01)\end{array}$ & $\begin{array}{l}-1144.08 \\
(1096.23)\end{array}$ \\
\hline
\end{tabular}

Robust standard errors in parenthesis, ${ }^{* *} p<0.01,{ }^{* *} p<0.05,{ }^{*} p<0.1$.

\section{References}

Afroz, Rafia, and Muhammad Mehedi Masud. 2011. Using a contingent valuation approach for improved solid waste management facility: Evidence from Kuala Lumpur, Malaysia. Waste Management 31: 800-8. [CrossRef] [PubMed]

Barre, Juliette. 2014. Waste Market in Urban Malawi-A Way out of Poverty? Msc dissertation, Swedish University of Agricultural Sciences, Uppsala, Sweden.

Bateman, Ian J., Richard T. Carson, Brett Day, Michael Hanemann, Nick Hanley, Tannis Hett, Michael Jones-Lee, Graham Loomes, Susana Mourato, Ece Özdemiroglu, and et al. 2001. Economic Valuation with Stated Preference Techniques: A Manual. Cheltenham: Edward Elgar.

Breffle, William S., Edward R. Morey, and Tymon S. Lodder. 1998. Using Contingent Valuation to Estimate Neighborhood's Willingness to Pay to Preserve Undeveloped Urban Land. Urban Studies 35: 715-27. [CrossRef]

Cameron, Trudy Ann, and John Quiggin. 1994. Estimation using contingent valuation data from a "Dichotomous choice with follow-up" questionnaire. Journal of Environmental Economics and Management 27: $218-34$. [CrossRef]

Carmona-Torres, Carmen, and Javier Calatrava-Requena. 2006. Bid Design and its Influence on the Stated Willingness to Pay in a Contingent Valuation Study. Paper presented at International Association of Agricultural Economists Conference, Gold Coast, Australia, August 12-18.

Czajkowski, Mikołaj, Tadeusz Kądziela, and Nick Hanley. 2014. We want to sort! Assessing households' preferences for sorting waste. Resource and Energy Economics 36: 290-306. [CrossRef]

DEFRA. 2007. An Introductory Guide to Valuing Ecosystem Services. London: Department for Environment, Food and Rural Affairs.

Government of Malawi. 2010. Malawi State of Environment and Outlook Report: Environment for Sustainable Economic Growth. Lilongwe: Environmental Affairs Department. ISBN 978-99960-21-00-8.

Hanemann, Michael, John Loomis, and Barbara Kanninen. 1991. Statistical Efficiency of Double-Bounded Dichotomous Choice Contingent Valuation. American Journal of Agricultural Economics 73: 1255-63. [CrossRef]

Hensher, David A. 2010. Hypothetical bias, choice experiments and willingness to pay. Transportation Research Part B: Methodological 44: 735-52. [CrossRef]

Honu, Bright. 2007. Contingent Valuation Method for General Practitioners: A Cookbook Approach. Lesotho Social Science Review 11: 83-96.

Hoornweg, Daniel, and Perinaz Bhada-Tata. 2012. What a Waste: A Global Review of Solid Waste Management. Urban Development Series Knowledge Paper. Washington, DC: World Bank.

Lopez-Feldman, Alejandro. 2012. Introduction to Contingent Valuation Using Stata. Munich Personal RePec Archive. Available online: http:/ / mpra.ub.uni-muenchen.de/41018/ (accessed on 20 September 2018).

Maganga, Assa. 2013. Emerging Solid Waste Market in Lilongwe Urban, Malawi: Application of Dichotomous Choice Contingent Valuation Method. Journal of Sustainable Development in Africa 15: 56-65. 
Maoulidi, Moumie. 2012. Water and Sanitation Needs Assessment for Blantyre City, Malawi. MCI Social Working Paper Series; New York: Millennium Cities Initiative, Columbia University. [CrossRef]

National Statistical Office. 2008. Population and Housing Census Report. Zomba: National Statistical Office.

Palamuleni, Lobina G. 2002. Effect of Sanitation Facilities, Domestic Solid Waste Disposal and Hygiene Practices on Water Quality in Malawi's Urban Poor areas: A Case study of South Lunzu Township in the city of Blantyre. Physics and Chemistry of the Earth 27: 845-50. [CrossRef]

Tilley, Elizabeth, and Isabel Günther. 2016. The Impact of Conditional Cash Transfer on Toilet Use in eThekwini, South Africa. Sustainability 10: 1070. [CrossRef]

Triola, Mario F. 2001. Elementary Statistics. Boston: Addison Wesley Longman, ISBN 9780201614800.

UN-Habitat. 2012. Recycling, Treatment and Disposal of Municipal Solid Waste in Low and Mddle-Income Countries: Perspectives for Municipal Managers and Environment Agencies. Nairobi: UN-Habitat.

World Bank. 2018. Available online: https://data.worldbank.org/country/malawi (accessed on 20 September 2018).

(C) 2018 by the authors. Licensee MDPI, Basel, Switzerland. This article is an open access article distributed under the terms and conditions of the Creative Commons Attribution (CC BY) license (http:/ / creativecommons.org/licenses/by/4.0/). 